\title{
ANÁLISE DO PÓLEN EM DEZOITO CULTIVARES DE MACIEIRA (')
}

\author{
FERNANDO ANTONIO CAMPO DALL'ORTO $\left({ }^{2,4}\right)$, WILSON BARBOSA $\left({ }^{2,5}\right)$, \\ MÁRIO OJIMA $\left({ }^{2}\right)$ e SONIA APARECIDA FERRAZ DE CAMPOS $\left({ }^{3}\right)$
}

\begin{abstract}
RESUMO
Como subsídio essencial ao projeto de melhoramento genético da macieira (Malus spp.) por hibridação e ao conhecimento da polinização natural nas condições do Estado de São Paulo, efetuaram-se estudos sobre a quantidade e a viabilidade do pólen existente em dezoito cultivares de maior interesse no momento. Constatou-se que, entre os cultivares mais utilizados nos cruzamentos, Anna, Brasil, Dulcina, Ein Shemer, Gala, Rainha e Valinhense, juntamente com as novas seleçōes - IAC 170-1 e IAC 570-38 - foram os que se apresentaram mais ricos de pólen, com número superior a 50.000 grãos por flor. Quanto à viabilidade polínica desse material estudado, a germinação situou-se em níveis bastante satisfatórios - quase sempre maior que $50 \%$ - mesmo quando se armazenou o pólen por um período de 70 dias, em ambiente frio $\left(-1^{\circ} \mathrm{C}\right)$ em dessecadores.
\end{abstract}

Termos de indexação: pólen, macieira, viabilidade, polinização, melhoramento.

(1) Trabalho experimental ligado ao Projeto: "Melhoramento genético da macieira - Malus spp." do Convênio SAA-IAC-EMBRAPA. Recebido para publicaçāo em 10 de janeiro de 1984.

$\left(^{2}\right)$ Seção de Fruticultura de Clima Temperado, Instituto Agronômico (IAC), Caixa Postal 28, 13100 - Campinas (SP).

$\left({ }^{3}\right)$ Seção de Fitoquímica, IAC.

${ }^{4}$ ) Com bolsa de suplementação do $\mathrm{CNPq}$.

$\left(\begin{array}{l}5 \\ 5\end{array}\right)$ Com bolsa de aperfeiçoamento do CNPq.

$\left({ }^{6}\right)$ Os autores agradecem aos pesquisadores Orlando Rigitano - consultor técnico da Divisão de Horticultura - e Neusa Diniz da Cruz - Seção de Citologia, a prestimosa colaboração na revisão do trabalho em epígrafe. 


\section{INTRODUÇÃo}

Dentro do desenvolvimento experimental do melhoramento genético da macieira, o conhecimento da quantidade e da capacidade de germinação do pólen de determinado cultivar assume importância primordial, quando se objetiva maior eficiência nos cruzamentos controlados. Além disso, confere ainda um direcionamento adequado à efetiva interpolinização dos cultivares envolvidos, além de prognosticar as possibilidades de êxito na autofertilização de novos materiais de maçã em fase final de seleção.

Um cultivar, para ser caracterizado apropriadamente como polinizante, deve produzir pólen viável em abundância, e apresentar periodo mais ou menos concomitante de florescimento ao receptor. A quantidade efetiva de pólen produzido é determinada pelo número total de flores da planta; pela quantidade de pólen por flor e pela sua viabilidade, tendo-se constatado que esses três fatores diferem entre os cultivares. Como parâmetros auxiliares nessa avaliação, podem ser utilizados os seguintes, que, em última análise, se complementam:

1) viabilidade do pólen;

2) número de grãos de pólen por antera e por flor, ou peso do pólen por flor;

3) número de flores por planta ou por hectare, por comprimento de ramo, por volume de copa, ou, ainda, por centímetro quadrado de tronco (CHURCH \& WILLIAMS, 1983).

Pesquisas pioneiras desenvolvidas nos EUA (KNOWLTON, 1935) já caracterizavam a produção de pólen em relação às variedades, por meio da contagem do número de grãos de pólen por antera, em flores de macieira. Entre outras de importância, era referida a 'Golden Delicious', com 4.255 a 7.194 grãos de pólen por antera, de flores colhidas em dois anos consecutivos, e contagens feitas com o auxílio de um hemocitômetro de Newbauer, sob o microscópio.

Em termos de dados referenciais, nas condições de Santa Catarina, por sua vez, mediante estudos de polinização varietal desenvolvidos com os cultivares Gala e Fuji, de diversas localidades, constataram-se, em média, 1.850 e 1.700 grãos de pólen por antera, e germinação de $40 \%$ e $70 \%$ respectivamente (PASQUAL et alii, 1980).

Enfim, para dar suporte aos trabalhos de melhoramento, desenvolveram-se, nas primaveras de 1982 e 1983, estudos preliminares visando ao maior conhecimento ligado à quantidade e viabilidade do pólen em dezoito cultivares de maçã, utilizados em "hibridações" no Instituto Agronômico (RIGITANO et alii, 1975, 1978). 


\section{MATERIAL E MÉTODOS}

Foram estudados dezesseis cultivares e duas recentes seleções de macieira existentes nos lotes de competição varietal, do Instituto Agronômico, nas Estações Experimentais dos seguintes locais do Estado de São Paulo:

Jundiaí: Anna, Dulcina (IAC 8-35), Golden Delicious, Michal, Mollies Spur, Mutsu, Prima, Rainha (IAC 8-31), Starkrimson e Willie Sharp;

Monte Alegre do Sul: Culinária (IAC 5-10), Fuji, Valinhense (Ohio Beauty), IAC 170-1 e IAC 570-38;

Tietê: Brasil (Brück ner), Ein Shemer e Gala.

As plantas produtoras das flores para o estudo, de dois a três anos de idade, foram submetidas a tratos culturais rotineiros, tais como amanho e adubação do solo, pulverizações sanitárias e de quebra de dormência, desbrotas e podas de condução ao natural. Colheram-se as flores em dois anos consecutivos - de 10 a 18 de setembro de 1982 , e de 9 de setembro a 20 de outubro de 1983 - tendo em vista serem as plantas ainda jovens, e algumas não terem ainda florescido na primavera de 1982 .

Coletaram-se duas amostras de 60 flores ao acaso, em estádio de balão, de três plantas de cada variedade, cultivadas num mesmo local. Logo depois de trazidas ao laboratório da Seção de Fruticultura de Clima Temperado, em Campinas, as flores foram preparadas como é descrito a seguir, à similaridade do que já se adotara com o pessegueiro $\left({ }^{7}\right)$ :

1) da primeira amostra, separaram-se 50 flores, extraíram-se e contaram-se suas anteras, depositando-as em papel filtro, sob luz, em placas de Petri. Após 24 horas de secagem, as anteras, juntamente com o pólen semiliberado, foram colocadas em frascos de vidro escuro, tapados com algodão, e armazenados a frio $\left(-1^{\circ} \mathrm{C}\right)$, em dessecadores, por um período de um a dois meses e meio;

2) da segunda amostra, a fim de avaliar o número de grãos de pólen por antera, elas eram retiradas das flores, sendo 50 colocadas em béqueres de $5 \mathrm{ml}$, sob luz, por 48 horas, para deiscênçia. A seguir adicionava-se $1 \mathrm{ml}$ de ácido lático, deixando a suspensão descansar por 24 horas, e colocava-se uma gota dessa solução sobre as câmaras de uma das placas de Newbauer, que era coberta com lamínula, para contagem ao microscópio.

( ${ }^{7}$ ) BARBOSA, W. Melhoramento genético de frutíferas do gênero Prunus ... Relatório semestral de Atividades do Bolsista, na Seção de Fruticultura de Clima Temperado, ao CNPq. Instituto Agronômico, Campinas, p. 30-34, agosto de 1983 (não publicado). 
Adotou-se para contagem a fórmula simplificada seguinte: $y=200 x$, na qual y representa o número estimado de grãos de pólen por antera, e, $\mathbf{x}$, o número médio de grãos de pólen contados na câmara, segundo metodologia utilizada por PASQUAL et alii (1980).

Para o teste de germinação do pólen, polvilhou-se cada material da primeira amostra, que se encontrava armazenado a frio seco, em lâminas contendo o meio constituído de ágar, glicose e água bidestilada, na seguinte proporção: $1 \mathrm{~g}: 10 \mathrm{~g}: 100 \mathrm{ml}$ respectivamente. Logo depois de preparadas, as lâminas eram levadas à câmara iluminada, a $28 \pm 2{ }^{\circ} \mathrm{C}$, por um período de quatro horas, sendo posteriormente realizado o protocolo da germinação, sob lupa estereoscópica. Para cada variedade, foram preparadas quatro lâminas e avaliados, em cada uma, quatro campos focais ao acaso, considerando-se como germinados os grãos de pólen que exibissem qualquer desenvolvimento visível do tubo polínico.

\section{RESULTADOS E CONCLUSOES}

Como se observa pelo quadro 1, entre os cultivares estudados, salientaram-se, quanto à abundância de pólen, os seguintes: Anna, Brasil, Dulcina, Ein Shemer, Gala, Rainha e Valinhense, e as novas seleções IAC 170-1 e IAC 570-38, com número superior a 2.500 grãos de pólen por antera, isto é, mais de 50.000 grãos de pólen por flor, ao passo que os cultivares Culinária, Fuji, Mutsu, Prima e Willie Sharp apresentaram-se com número inferior a 2.000 grãos de pólen por antera, isto é, menos de 40.000 grãos de pólen por flor. Admite-se, por experiência de observações locais, que determinado cultivar, de potencial a ser utilizado como polinizante, deva apresentar, entre outras características de relevância, como capacidade efetiva de aclimação e de produção de flores, uma quantidade de pólen viável, representada por um número acima de 20.000 grãos por flor.

Constata-se, desse modo, que no primeiro grupo constam os mais importantes cultivares em exploração comercial nas regiões de inverno brando do Estado de São Paulo: Valinhense, Brasil, Rainha, Anna e seu polinizante Ein Shemer, à exceção do Culinária (RIGITANO et alii, 1975, 1978); contudo, este deve, ainda, merecer prioridade nos plantios comerciais como opção vantajosa ao 'Valinhense', por sua produtividade, ou mesmo como polinizante, devido à profusão de seu florescimento, o que compensa o menor número relativo de grãos de pólen por flor. $\mathrm{O}$ 'Gala', que apresentou o maior número absoluto de grãos de pólen por flor, um dos recomendados para o cultivo na região Sul do País, também vem sendo plantado nos últimos anos, com muita expectativa, nas áreas mais frias paulistas. Esta colocação é devida ao seu comportamento adaptativo marginal às condições climatoedáficas prevalecentes no Estado, e a não prescindir de rigoroso tratamento de quebra 


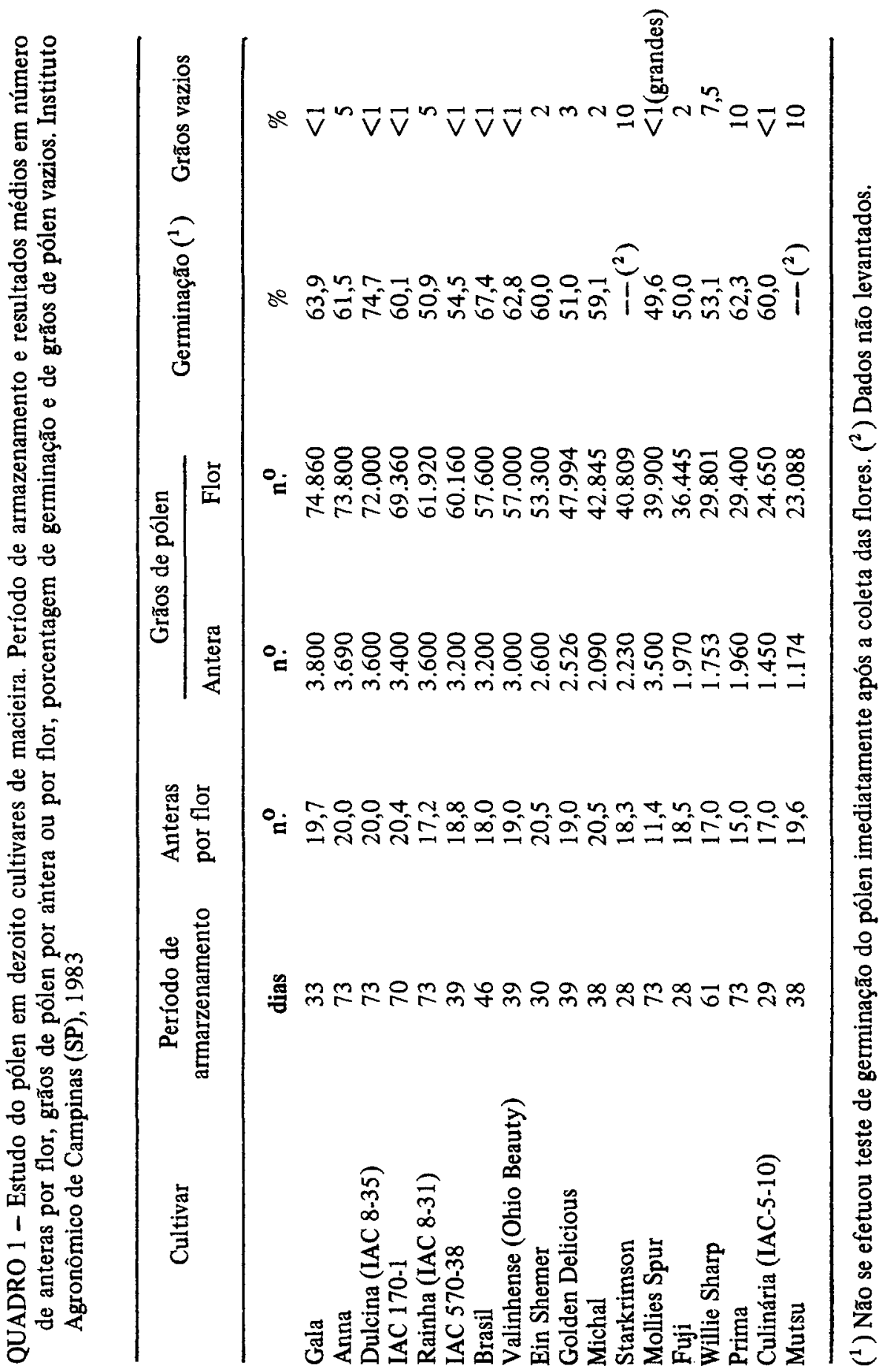


de dormência para indução de pleno florescimento. Por sua vez, as seleçōes IAC 170-1 e IAC 570-38, híbridos em fase final de averiguações fitotécnicas, constituem material dos mais promissores para breve lançamento ao plantio comercial.

A germinação do pólen em todas as variedades estudadas situou-se em níveis satisfatórios, superior ou em torno do índice de $50 \%$, mesmo sob armazenamento em ambiente controlado - frio e seco - por mais de 70 dias. Esse resultado, por si só, afigura-se promissor e de grande interesse aplicado nos trabalhos de melhoramento genético da macieira, que visa à obtenção de cultivares mais precoces: possibilita, não só, a utilização de paternais de florescimento bem antecipado, como, também, a estocagem do pólen das variedades de interesse, por período superior a dois meses após a coleta das flores.

\title{
SUMMARY \\ POLLEN ANALYSIS OF EIGHTEEN APPLE CULTTVARS
}

\begin{abstract}
Aiming to find out variations in pollen quantity and viability in eighteen apple cultivars, analysis of "in vitro" germination was performed to contribute - as a parameter for genetic breeding by hybridization and as a pollination basis. The apple cultivars or selections recommended for commercial planting, at the mild climate conditions prevailing in the State of São Paulo, Brazil, and most utilized in crosses, are nowadays the following: Anna, Brasil, Dulcina, Ein Shemer, Gala, Rainha, Valinhense, IAC 170-1 and IAC 570-38. These cultivars presented more than 50 thousand pollen grains per one flower. The germination index observed (also an indicator of pollen viability) was higher than 50 percent in great number of materials, indicating that the pollen of the apple plant, well prepared, can be stored in a cold and dry environment (a desiccator at $-1^{\circ} \mathrm{C}$ ) during a period of about 70 days.
\end{abstract}

Index terms pollen, apple tree, viability, pollination, breeding.

\section{REFERÊNCIAS BIBLIOGRÁFICAS}

CHURCH, R.M. \& WILLIAMS, R.R. Comparison of flower numbers and pollen production of several dessert apple and ornamental Malus cultivars. Journal of Horticultural Science, 58(3):327-336, 1983.

KNOWLTON, H.E. The relative abundance of pollen production by varieties of apples. Proceedings of the American Society for Horticultural Science, 33:7-9, 1935.

PASQUAL, M.; PETRI, J.L. \& PEREIRA, A.D. Estudos sobre a polinização dos cultivares de macieiras Gala e Fuji. Revista Brasileira de Fruticultura, Campinas, 2(3):56-72, 1980. 
RIGITANO, O.; OJIMA, M. \& CAMPO DALL'ORTO, F.A. Comportamento de sete cultivares de maçã subtropical introduzidos no Estado de São Paulo. Campinas, Instituto Agronômico, 1978. 15p. (Boletim técnico, 31)

\& paulista. Campinas, Instituto Agronômico, 1975. $11 \mathrm{p}$. (Boletim técnico, 31) 